\title{
HUBUNGAN KREDIBILITAS PUSTAKAWAN DENGAN LOYALITAS PEMUSTAKA PADA PERPUSTAKAAN UNISBA
}

\author{
Dwininda Kusumawardhani \\ Universitas Padjadjaran Bandung, Jawa Barat, Indonesia \\ dwinindakw@gmail.com \\ Tine Silvana Rachmawati \\ Universitas Padjadjaran Bandung, Jawa Barat, Indonesia \\ tine_silvana@yahoo.com \\ Prijana \\ Universitas Padjadjaran Bandung, Jawa Barat, Indonesia \\ prijanafikom@gmail.com
}

\begin{abstract}
This research is about the credibility of librarians with user loyalty in the UNISBA library. This study uses the credibility theory of Hovland, Janis, and Kelly (1993). The aim is to find out how the relationship between librarian credibility aspects is expertise, trustworthiness, and attractiveness with user loyalty. Samples from this study were members of the UNISBA library, with sampling techniques using quota sampling techniques. This study uses a correlational method with descriptive and inferential statistical analysis techniques using Pearson product moment test. The results of this study are the relationship between the credibility of librarians and user loyalty which there is a significant relationship between the credibility of librarians and user loyalty and included in the medium category. Based on the test using the Pearson moment event method, the coefficient
\end{abstract}


was obtained $\rho=0.537 ; \rho 2=0.288 ; \alpha=0.05 ; n=102 ; d k=100$, obtained the results of $t$ count $=6.366$ and $t$ table $=1.984$, then the value is significant because thitung $>t$ table. The conclusion of this study is that this shows that the credibility of the librarian will encourage the loyalty of users to come back to the library because they feel good by the librarian.

Keywords: credibility, librarian, loyality users

\begin{abstract}
Abstrak
Penelitian ini mendiskusikan tentang hubungan kredibilitas pustakawan dengan loyalitas pemustaka pada perpustakaan UNISBA. Penelitian ini menggunakan teori kredibilitas sumber dari Hovland, Janis, dan Kelly (1993). Tujuannya adalah mengetahui bagaimana hubungan yang terjadi antara aspek kredibilitas pustakawan yaitu keahlian, keterpercayaan, dan daya tarik dengan loyalitas pemustaka. Sampel dari penelitian ini adalah anggota perpustakan UNISBA, dengan teknik pengambilan sampel menggunakan teknik sampling kuota. Penelitian ini menggunakan metode korelasional dengan teknik analasis statistik deskriptif dan inferensial menggunakan uji pearson product moment. Hasil penelitian ini adalah hubungan antara kredibilitas pustakawan dengan loyalitas pemustaka terdapat hubungan yang signifikan antara kredibilitas pustakawan dengan loyalitas pemustaka dan termasuk dalam kategori sedang. Berdasarkan uji korelasi menggunakan metode korelasi pearson product moment didapat koefisien korelasi $\rho=0,537 ; \rho^{2}=0,288 ; \alpha=0,05 ; \mathrm{n}=$ $102 ; \mathrm{dk}=100$, didapatkan hasil $\mathrm{t}_{\text {hitung }}=6,366 \mathrm{dan}_{\mathrm{tabel}}=1,984$, maka dinyatakan signifikan karena $t_{\text {hitung }}>t_{\text {tabel }}$ Kesimpulan penelitian ini adalah hal ini menunjukan bahwa dengan kredibilitas yang dimiliki oleh pustakawan akan mendorong loyalitas pemustaka untuk datang kembali ke perpustakaan karena merasa dilayani dengan baik oleh pustakawan.
\end{abstract}

Kata Kunci: kredibilitas, pustakawan, loyalitas pemustaka 


\section{A. Pendahuluan}

Perpustakaan perguruan tinggi merupakan suatu unsur penunjang perguruan tinggi untuk melaksanakan Tridharma perguruan tinggi. ${ }^{1}$ Selaras pendapat dari Sulistyo Basuki (1991) mendefisikan perpustakaan perguruan tinggi adalah perpustakaan yang terdapat pada perguruan tinggi, badan bawahannya, maupun lembaga yang berafiliasi dengan perguruan tinggi. ${ }^{2}$

Terdapat beberapa unsur terpenting di perpustakaan guna menunjang operasional perpustakaan, diantaranya adalah pustakawan. Pustakawan menurut UU No 43 Tahun 2007 adalah seorang professional yang bekerja di perpustakaan yang memiliki kompetensi didapatkan melalui pendidikan dan/atau pelatihan dengan memiliki tugas dan tanggungjawab untuk melaksanakan pengelolaan dan pelayanan. ${ }^{3}$

Menurut data PERPUSNAS hingga Desember tahun 2017 jumlah pustakawan di Indonesia terdapat sebanyak 2846 orang. Terbagi kedalam beberapa kateogori perpustakaan yaitu pustakawan di perpustakaan sekolah sebanyak 133 orang, perguruan tinggi sebanyak 1264 orang, perpustakaan khusus sebanyak 393 orang, perpustakaan umum provinsi sebanyak 624 orang, di perpustakaan nasional sebanyak 263 orang dan perpustakaan umum kabupaten/ kota sebanyak 169 orang. ${ }^{4}$

Berdasarkan data tersebut, pustakawan di perpustakaan perguruan tinggi masih reletif sedikit. Berikut merupakan rincian jabatan pustakawan di perpustakaan tinggi seperti pustakawan

${ }^{1}$ Rismayeti, "Perpustakaan Perguruan Tinggi : Pedoman, Pengelolaan Dan Standarisasi," Jurnal Ilmu Budaya Vol. 9, No. 2 (2013), https://www.ejurnal. unilak.ac.id/index.php/jib/article/view/211/158.

2 Imran Benawi, "Mengenal Lebih Dekat Perpustakaan Perguruan Tinggi," Jurnal Iqra Vol.06, No. 01 (2012): 49-62, https://doi.org/10.1093/ oxfordhb/9780199607617.013.31.

3 Triana Santi, "Keterampilan Teknis Pustakawan," Jurnal Iqra Vol.06, No.01 (Mei 2012): 38-44.

4 Perpustakaan Nasional Republik Indonesia, "Statistik Pustakawan Desember 2017 Pusat Pengembangan Pustakawan PNRI," 2018, http:// pustakawan.perpusnas.go.id/pub/pustakawanstatistics? mode=monthly\&option =stat\&stat_month=12\&stat_year=2017. 
pelaksana sebanyak 78 orang, pustakawan lanjutan sebanyak 143 orang, pustakawan penyelia sebanyak 214 orang, pustakawan pertama sebanyak 228 orang, pustakawan muda sebanyak 314, pustakawan madya sebanyak 267 orang dan pustakawan utama hanya 11 orang. ${ }^{5}$

Perpustakaan UNISBA merupakan perpustakaan perguruan tinggi yang sangat memiliki peranan penting sebagai sarana pemenuhan kebutuhan informasi yang diinginkan oleh civitas akademika. Berbagai macam sumber informasi dari berbagai sumber dapat dijadikan sebagai bahan rujukan penambahan informasi oleh pemustaka dan berbagai macam layanan yang diberikan guna mengembangakan kualitas pustakawan maupun pemustaka yang berkunjung ke perpustakaan.

Perpustakaan UNISBA memiliki SDM (Sumber Daya Manusia) pada tahun 2017 berjumlah 11 orang yang terdiri dari 8 orang pustakawan, 2 orang staf perpustakaan dan 1 orang tata laksana. Dalam melakukan seleksi pustakawan, Perpustakaan UNISBA memiliki ketentuan khusus yaitu pustakawan harus memiliki pengetahuan dan keterampilan tentang perpustakaan, mampu berkomunikasi dengan baik, dapat mengikuti perkembangan teknologi informasi, serta mampu bersikap sopan, ramah, jujur dan bertanggung jawab. Sehingga pustakawan diharapkan menjadi manusia unggul yang memiliki keterampilan pengetahuan dan perilaku dalam rangka memberikan kontribusi positif terhadap pengembangan perpustakaan, hal ini dilakukan agar pemustaka mendapatkan pelayanan prima dari seorang pustakawan yang ada diperpustakaan UNISBA.

Pustakawan juga diharuskan memiliki kemampuan mengemas informasi dengan menarik untuk disampaikan pada pemustaka. Informasi ini berguna untuk memberikan stimulus

\footnotetext{
${ }^{5}$ Perpustakaan Nasional Republik Indonesia.
} 
positif pada pemustaka yang dilakukan dengan cara berkomunikasi secara personal. ${ }^{6}$

Dari penjelasan dapat dikatakan bahwa pustakawan memiliki kredibilitas di bidang perpustakaan apabila pustakawan telah memiliki pengatahuan, pengalaman, etika yang baik serta memiliki kemampuan dalam berkomunikasi dengan pemustaka.

Menurut Rakhmat dalam bukunya Psikologi Komunikasi mengungkapkan bahawa kredibilitas adalah komunikasi tentang sifat-sifat komunikator. Dalam definisi ini terkandung 2 hal yaitu kredibilitas adalah persepsi dari komunikan jadi selaras dengan diri komunikator, dan kredibilitas yang berkenaan dengan sifatsifat komunikator yang kita sebut sebagai komponen kredibilitas. ${ }^{7}$

Menurut Hovland (1953) Kredibilitas sumber sendiri terdiri atas dari keahlian, keterpercayaan serta daya tarik. ${ }^{8}$ Dapat diasumsikan bahwa komunikator yang memiliki kredibilitas dapat merubah sikap ataupun persepsi yang dimiliki oleh komunikannya. Rakhmat (2007) mengatakan kredibilitas bukan hanya citra pada diri komunikator namun kredibilitas dapat dibentuk dan dibangun sesuai dengan tujuan masing-masing perpustakaan. ${ }^{9}$

Salah satu keuntungan dari kredibilitas adalah agar tercipta komunikasi yang baik antara pustakawan dan pemustaka. Dengan tercipta suasana yang nyaman karena pemustaka merasa dilayani dengan baik oleh pustakawan, sehingga pemustaka tersebut memiliki memori kesan yang baik dengan mengatakan hal-hal positif kepada orang lain dan merekomendasikan kepada orang lain untuk datang ke perpustakaan tanpa mendapatkan suatu imbalan tertentu perilaku ini disebut loyalitas. $49-62$.

${ }^{6}$ Benawi, "Mengenal Lebih Dekat Perpustakaan Perguruan Tinggi," 7 Jalaludin Rakhmat, Psikologi Komunikasi (Bandung: Rosda Karya, 2005).

8 Alexis S. Tan, Pengantar Teori dan Manajemen Komunikasi (jakarta: Jurnal Press, 1981).

9 Rakhmat, Psikologi Komunikasi. 
Loyalitas adalah sikap seseorang terhadap suatu objek yang memiliki keinginan untuk menjaga, memiliki, dan merekomendasikan kepada orang lain terhadap objek. ${ }^{10}$ Sehingga pada konteks ini loyalitas pada pemustaka adalah sikap seseorang yang memiliki keinginan untuk ikut serta dalam melakukan pengembangan di perpustakaan, memberikan saran untuk perbaikan sarana dan prasaran, merekomendasikan bahan bacaan, dan ikut melestarikan perpustakaan.

Terdapat beberapa penelitian mengenai kredibilitas pustakawan dengan loyalitas pemustaka, seperti penelitian awal yang dilakukan oleh Hovland, Janis, \& Kelley (1953) menemukan bahwa keahlian dan kredibilitas sumber dianggap sebagai dua komponen yang dianggap penting dari kredibilitas sumber. Meskipun hal ini diungkapkan mereka pun mengakui bahwa dampak pesan yang disampaikan tergantung pada saluran atau publikasi tertent. ${ }^{11}$ Penelitian selanjutnya dilakukan oleh Amin Saleh (2014) mengemukakan bahwa kredibilitas dipandang berpengaruh meliputi kompetensi, sikap, tujuan, kepribadian dan dinamika pustakawan yang memepengaruhi kepuasan pemustaka dengan aspek keandalan, responsiv, keyakinan, emapati, dan wujud fisik. ${ }^{12}$

Dengan jumlah pengunjung bulan September 2016 sebanyak 2273 orang dan rata-rata jumlah pengunjung tinggi. Sehingga menurut peneliti hal ini sangat penting untuk diteliti karena perpustakaan memiliki pustakawan dengan kredibilitas baik dan jumlah pengunjung yang tinggi setiap bulannya, apakah kedua aspek ini saling berhubungan atau malah tidak memiliki hubungan sama sekali karena ada faktor-faktor penyebab lainnya.

\footnotetext{
${ }^{10}$ Fandy Tjiptono, Manajemen Jasa (Yogyakarta: Andi Offset, 2000).

11 Antar Venus, Manajemen Kampanye: Panduan Teoritis Dan Praktis (Bandung: Simbiosa, 2004).

12 Amin Saleh, "Pengaruh Kredibilitas Pustakawan Pada Layanan Referensi Terhadap Kepuasan Pemustaka Di Badan Perpustakaan Dan Arsip Daerah Provinsi Nusa Tenggara Barat," Ilmu Perpustakaan Vol.1, No.1 (2014): $1-15$.
} 
Berdasarkan latar belakang yang telah diuraikan diatas, maka dapat dirumuskan permasalahannya adalah "Apakah Kredibilitas Pustakawan Memiliki Hubungan Signifikan Dengan Loyalitas Pemustaka?". Selanjutnya dapat diuraikan identifikasi masalahnya adalah sebagai berikut: (1) Apakah keahlian pustakawan memiliki hubungan signifikan denga loyalitas pemustaka. (2) Apakah keterpercayaan pustakawan memimiliki hubungan signifikan dengan loyalitas pemustaka. (3) Apakah daya tarik pustakawan memiliki hubungan siginifikan dengan loyalitas pemustaka

Tujuan penelitian: (1) Untuk mengetahui hubungan antara kredibilitas pustakawan dan loyalitas pemustaka. (2) ntuk mengetahui hubungan antara keahlian pustakawan dan loyalitas pemustaka. (3) Untuk mengetahui hubungan antara keterpercayaan pustakawan dan loyalitas pemustaka. (4) Untuk mengetahui hubungan antara daya tarik pustakawan dan loyalitas pemustaka.

Hipotesis: (1) $\mathrm{H}_{0}$ : Tidak terdapat hubungan signifikan antara kredibilitas pustakawan dengan loyalitas pemustaka, $\mathrm{H}_{1}$ : Memiliki hubungan signifikan antara kredibilitas pustakawan dengan loyalitas pemustaka. (2) $\mathrm{H}_{0}$ : Tidak terdapat hubungan signifikan antara keahlian pustakawan dengan loyalitas pemustaka, $\mathrm{H}_{1}$ : Memiliki hubungan signifikan antara keahlian pustakawan dengan loyalitas pemustaka. (3) $\mathrm{H}_{0}$ : Tidak terdapat hubungan signifikan antara keterpercayaan pustakawan dengan loyalitas pemustaka, $\mathrm{H}_{1}$ : Memiliki hubungan signifikan antara keterpercayaan pustakawan dengan loyalitas pemustaka. (4) $\mathrm{H}_{0}$ : Tidak terdapat hubungan signifikan antara daya tarik pustakawan dengan loyalitas pemustaka, $\mathrm{H}_{1}$ : Memiliki hubungan signifikan antara daya tarik pustakawan dengan loyalitas pemustaka

Metode penelitian yang digunakan dalam penelitian ini adalah menggunakan penelitian kuantitatif yang berarti penelitian yang akan selalu berbasiskan data maka dari itu penelitian ini akan menggunakan metode survey sebagai metode yang digunakan oleh 
peneliti sebagai cara untuk mengumpulkan dan menjelaskan suatu data yang dikumpulkan melalui kegiatan obeservasi. ${ }^{13}$

Dan untuk perhitungan statistik, pada penelitian ini menggunakan Method Successive of Interval (MSI), MSI adalah sebuah metode statistik yang memiliki langkah-langkah kerja untuk mengubah skala ordinal yang diperoleh dari data observasi lapangan menjadi skala interval. ${ }^{14}$

Dalam menentukan sampling, penelitian ini menggunakan menggunakan teknik sampling kuota. Pada penelitian di perpustakaan UNISBA memiliki beberapa subpopulasi karena memiliki jumlah populasi yang sangat beragam dan untuk menentukan unit sampling pada sampling kuota menggunakan cara yang sama seperti pada mengambil unit sampling pada sampling strata karena untuk menghindari sampling yang bias. ${ }^{15}$

\section{B. Pembahasan}

Pada bagian ini akan membahas mengenai bagaimana kredibilitas pustakawan di perpustakaan UNISBA berdasarkan teori yang dikemukakan oleh Hovland, Jenni dan Kelley (1953) dalam buku manajemen kampanye (Venus, 20004) kredibilitas terdiri dari keahlian (expertise), Keterpercayaan (trustworthiness), dan daya tarik (attractiveness). Dan untuk menjelaskan loyalitas pemustaka menurut Tjiptono (2000) dapat diukur berdasarkan 3 indikator yaitu memori kesan, rekomendasi kepada orang lain, melakukan kunjungan kembali. ${ }^{16}$

${ }^{13}$ Yunus Winoto Prijana dan Andri Yanto, Metode Penelitian Kuantitatif Ilmu Perpustakaan Dan Informasi (Bandung: Unpad Press, 2016).

${ }_{14}$ Prijana dan Andri Yanto.

${ }_{15}$ Prijana dan Andri Yanto.

16 Tjiptono, Manajemen Jasa. 


\section{Ketegori Jawaban Penelitian}

\section{a. Kredibilitas Pustakawan UNISBA}

Kredibilitas pustakawan adalah persepsi yang diberikan oleh pemustaka tentang kemampuan pustakawan dalam hubungannya dengan topik yang sedang dibicarakan. ${ }^{17}$

Berdasarkan hasil yang diperoleh pada penelitian ini menunjukan bahwa kredibilitas yang dimiliki oleh pustakawan di UNISBA termasuk dalam kategori yang cukup atau biasa.

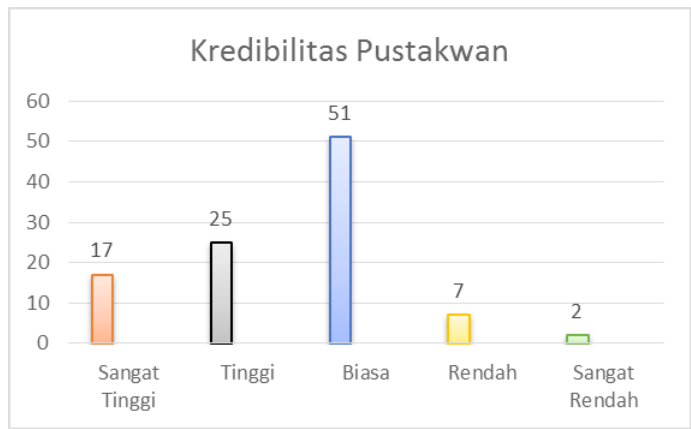

\section{Grafik 1-1 Hasil Kategori Variabel Kredibilitas Pustakawan}

Dengan kredibilitas termasuk dalam kategori cukup ini pustakawan dinilai sudah memiliki kredibilitas pada bidang perpustakaan, karena untuk membangun sebuah kredibilitas pustakawan diperlukan usaha yang kuat meningkatkan aspek keahlian seperti dengan mengikuti pelatihan baik itu pelatihan bahasa, teknologi maupun tentang perpustakaannya itu sendiri, aspek keterpercayaan yaitu dengan cara mengasah kemampuan cara berkomunikasi, selalu berkata jujur, dan memiliki tanggung jawab yang lebih dan aspek daya tarik yaitu dengan cara meningkatkan kepribadian seorang pustakawan. Dengan cara ini lah seorang pustakawan harus mampu mendengarkan dan mengikuti kritik, saran dan harapan dari pemustaka sehingga pemustaka yang datang merasakan kenyamanan dan kepuasan yang akan memicu timbulnya loyalitas pemustaka

\footnotetext{
${ }^{17}$ Venus, Manajemen Kampanye: Panduan Teoritis Dan Praktis.
} 


\section{b. Loyalitas Pemustaka}

Loyalitas pemustaka menurut Jennie (1997) dalam nuraini mengatakan adalah pemustaka yang merasa puas terhadap layanan yang diberikan oleh pustakawan di perpustakaan sehingga mempunyai antusiasme untuk memperkenalkan dan memberitahukan kepada siapapun yang mereka kenal, pada tahap selanjutnya pemustaka yang loyal akan memperluas kesetiaannya kapada layanan-layanan yang disediakan oleh perpustakaan. ${ }^{18}$

Berdasarkan hasil yang diperoleh pada penelitian ini menunjukan bahwa loyalitas yang dimiliki oleh pemustaka pada perpustakaan UNISBA termasuk dalam kategori yang cukup.

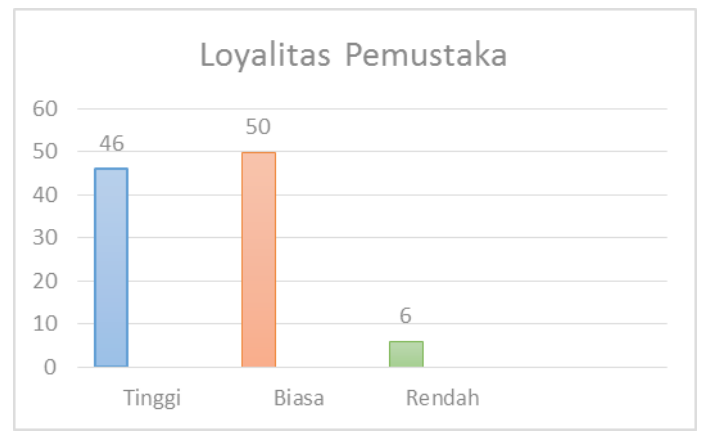

\section{Grafik 1-2 Hasil Kategori Variabel Loyalitas Pemustaka}

Dengan loyalitas pemustaka termasuk dalam kategori cukup ini berarti pemustaka sudah merasa cukup puas dengan pelayanan yang diberikan oleh pemustaka hal ini dapat menjadikan dorongan kepada pustakawan untuk meningkatkan kredibilitas yang dimiliki nya, jika pustakawan memiliki kredibilitas yang tinggi tidak menutup kemungkinan bahwa loyalitas pemustaka pun akan meningkat.

Selaras dengan pendapat Tjiptono (2001:126) yang mengemukakan bahwa loyalitas pemustaka adalah nilai pelayanan yang sesuai dengan harapan dan kinerja yang dirasakan oleh

18 Ropinov Saputro, "Analisis Pengaruh Kualitas Produk, Kualitas Pelayanan, Dan Kepercayaan Pelanggan Terhadap Loyalitas Pelanggan" (Universitas Diponegoro, 2010). 
pemustaka sehingga dapat memberikan kepuasan yang akan mendorong pemustaka menimbulkan loyalitas pelanggan

Dengan demikian loyalitas yang terjadi di perpustakaan UNISBA adalah sebagai berikut pemustaka memiliki kesan yang baik terhadap layanan yang berada di perpustakaan, pemustaka merasa puas ketika mendapatkan pelayanan dari pustakawan, dengan perasaan puas tersebut pemustaka memberikan rekomendasi secara tidak langsung kepada orang-orang disekitarnya, dan pastinya pemustaka itu melakukan kunjungan kembali ke perpustakaan sebagai tempat utama dalam mencari sebuah informasi yang terbaru, teraktual dan dapat dipercaya karena memperoleh sumber yang tepat.

Berdasarkan penjelasan diatas bahwa pemustaka berada di perpustakaan UNISBA dapat dikatakan sebagai pemustaka yang loyal terhadap perpustakaan dikarenakan tingkat kunjungan kembali pemustaka setiap bulannya termasuk dalam kategori tinggi, dan ikut memberikan kritik saran serta harapan untuk membangun perpustakaan lebih baik lagi dan akan memberikan pelayanan yang prima baik itu dari pustakawan yang melayani, fasilitas, koleksi yang berada di perpustakaan, ketika semua itu dilakukan hal ini akan mendorong pemustaka untuk meningkatkan loyalitas kepada perpustakaannya.

\section{Uji Hipotesis}

Berdasarkan hipotesis yang ada didapatkan hasil analisis dan interpertasi terhadap penelitian yang berjudul hubungan kredibilitas pustakawan dengan loyalitas pemustaka pada Perpustakaan UNISBA, sebagai berikut:

\section{a. Hubungan Kredibilitas Pustakawan dengan Loyalitas Pemustaka}

Kredibilitas pustakawan memiliki hubungan signifikan dengan loyalitas pemustaka. Hasil uji korelasi dengan menggunakan metode korelasi pearson product moment didapat koefisien korelasi $\rho=0,537 ; \rho^{2}=0,288 ; \alpha=0,05 ; \mathrm{n}=102 ; \mathrm{dk}=100$, didapatkan hasil 
$t_{\text {hitung }}=6,366$ dan $t_{\text {tabel }}=1,984$, maka dinyatakan signifikan karena $\mathrm{t}_{\text {hitung }}>\mathrm{t}_{\text {tabel. }}$

Selanjutnya dilakukan pentafsiran hasil menggunakan tabel intepretasi guilford

Tabel 1.1 Interpretasi Guilford

\begin{tabular}{ll}
\hline Interval Koefisien & Tingkat Hubungan \\
\hline $0,00-0,199$ & Korelasi Sangat Rendah \\
\hline $0,20-0,399$ & Korelasi Rendah \\
\hline $0,40-0,599$ & Korelasi Sedang \\
\hline $0,60-0,799$ & Korelasi Kuat \\
\hline $0,80-1,00$ & Korelasi Sangat Kuat \\
\hline
\end{tabular}

Maka dinyatakan bahwa hubungan antara kredibilitas pustakawan dengan loyalitas pemustaka termasuk pada kategori korelasi sedang/moderat yaitu memiliki hubungan yang sedang artinya kredibilitas pustakawan yang sedang memicu loyalitas pemustaka karena dengan pustakawan yang memiliki kredibilitas baik maka pemustaka akan mendapatkan pengetahuan yang dibutuhkan, merasa dilayani dengan baik dan akan memicu loyalitas pemustaka pada perpustakaan.

Kredibilitas adalah seberapa besar pemustaka melihat pustakawan memiliki pengetahuan, keterempilan atau pengalaman untuk memberikan informasi kepada pemustaka yang mereka butuhkan secara objektif sesuai dengan keahlian mereka. Selaras dengan pendapat Hovland ketika seseorang memiliki kredibilitas pada suatu bidang maka akan lebih mudah untuk mempersuasi orang lain. ${ }^{19}$

Pustakawan yang memiliki komunikasi yang baik akan mampu memperoleh dan bertanggungjawab dengan tugas yang dimilikinya, kompetensi ini sangat penting dimiliki oleh seorang

19 Yunus Winoto, "The Application of Source Credibility Theory in Studies about Library Services," EduLib Vol.05, No.2 (2015): 3-5. 
pustakawan karena jika pustakawan sudah memiliki komptensi yang baik akan memudahkan untuk memberikan informasi yang akan diberikan kepada pemustaka dan akan memberikan kelancaran dalam melakukan aktivitas sebagai seorang pustakawan. ${ }^{20}$

Dengan memiliki banyak pengetahuan dan pengalaman, pustakawan akan lebih mudah untuk menjelaskan isi pesan yang ingin disampaikan dan memberikan contoh penyelesaian masalah yang sedang dihadapi oleh pemustaka. ${ }^{21}$

Sehingga informasi yang disampaikan oleh pustakawan yang sudah dianggap ahli secara tidak langsung akan memiliki daya pengaruh yang besar terhadap pola pemikiran atau tindakan pemustaka yang memiliki kebutuhan informasi. Maka dari itu kredibilitas pustakawan dianggap sebagai keahlian untuk mempengaruhi pemustaka yang diajak berkomunikasi.

Sebagaimana yang diketahui bahwa tujuan dari perpustakaan yaitu menciptakan pelayanan yang prima sehingga pemustaka yang datang itu merasa nyaman dan puas. Dengan terciptanya kepuasan pemustaka dapat memberikan manfaat yaitu hubungan antara pustakawan dan pemustaka lebih terjaga dan akan memberikan dampak bagi perpustakaan yaitu loyalitas pemustaka. ${ }^{22}$

Dengan demikian, hubungan yang sedang antara kredibilitas pustakawan dengan loyalitas pemustaka dapat dikatakan sudah baik sehingga untuk mencapai hubungan yang kuat perlu ditingkatkan lagi keahlian, keterpercayaan dan daya tarik dari pustakawan dengan mengikuti beberapa pelatihan baik itu tentang perpustakaan, bahasa, maupun pengembangan diri dan pustakawan juga harus memperhatikan kritik, saran dan harapan yang diberikan oleh pemustakanya sebagai acuan memperbaiki kualitas pelayanan yang

\footnotetext{
${ }^{20}$ Abdul Karim, "Urgensi Kompetensi Komunikasi Pustakawan Dalam Memberikan Layanan Kepada Pemustaka," Iqra Vol.05, No.1 (2011): 5.

${ }^{21}$ Winoto, "The Application of Source Credibility Theory in Studies about Library Services," 3-5.

${ }_{22}$ Mardikawati Woro dan Farida Naili, "Pengaruh Nilai Pelanggan Dan Kualitas Layanan Terhadap Loyalitas Pelanggan, Melalui Kepuasan Pelanggan Pada Pelanggan Bus Efisiensi," Jurnal Administrasi Bisnis Vol.02, No. 01 (2013): $64-75$.
} 
berada diperpustakaan, jika hal ini dilakukan maka pemustaka yang datang tidak akan sungkan untuk memberikan tanggapan positif, merekomendasikan perpustakaan kepada orang lain untuk datang keperpustakaan, dan melakukan kunjungan kembali dalam waktu tertentu, dengan meningkatnya loyalitas pemustaka tentu saja ini akan menjadi keuntungan tersendiri bagi perpustakaan karena secara tidak langsung perpustakaan dipromosikan melalui Word Of Mouth (WOM).

\section{b. Hubungan Antara Keahlian Dengan Loyalitas Pemustaka.}

Keahlian pustakawan memiliki hubungan signifikan dengan loyalitas pemustaka. Hasil uji korelasi dengan menggunakan metode korelasi pearson product moment didapatkan hasil koefisien korelasi $\rho=0.362 ; \rho^{2}=0.131 ; \alpha=0.05 ; \mathrm{n}=102 ; \mathrm{dk}=100$, didapatkan hasil $\mathrm{t}_{\text {hitung }}=3.883$ dan $\mathrm{t}_{\text {tabel }}=1.984$, maka dinyatakan signifikan karena $\mathrm{t}_{\text {hitung }}>\mathrm{t}_{\text {tabel }}$

Selanjutnya dilakukan pentafsiran hasil menggunakan tabel intepretasi guilford

Tabel 1.2 Interpretasi Guilford

\begin{tabular}{ll}
\hline \multicolumn{1}{c}{ Interval Koefisien } & \multicolumn{1}{c}{ Tingkat Hubungan } \\
\hline $0,00-0,199$ & Korelasi Sangat Rendah \\
\hline $0,20-0,399$ & Korelasi Rendah \\
\hline $0,40-0,599$ & Korelasi Sedang \\
\hline $0,60-0,799$ & Korelasi Kuat \\
\hline $0,80-1,00$ & Korelasi Sangat Kuat \\
\hline
\end{tabular}

Maka dinyatakan bahwa hubungan antara keahlian pustakawan dengan loyalitas pemustaka termasuk pada kategori korelasi rendah/low correlation yaitu hubungan yang rendah artinya dengan seseorang ahli dalam bidang perpustakaan tidak menjadi faktor utama yang menjadikan pemustaka untuk loyal terhadap perpustakaan. 
Faktor keahlian berhubungan dengan penilaian dimana sumber dianggap mahir dalam berkomunikasi antar internal organisasi dan ekternal dengan organisasi yang lain. ${ }^{23}$

Keahlian bergantung pada keterlatihannya, pengalaman, dan status sosialnya, jadi ketika seseorang sumber dikatakan ahli adalah seorang yang pengetahuannya diakui dan dipercaya tentang pokok permasalah.

Menurut Murphy (1991) dalam Competencies for Special Librarians of the 21st Century (2003) mengemukakan bahwa kompetensi yang dimiliki oleh pustakawan adalah perpaduan antara pengetahuan, pemahaman, keahlian dan atribut-atribut lain yang harus dipenuhi untuk melakukan pekerjaan secara efektif baik dari sudut pandang pekerja maupun pengguna jasa (dalam hal ini pustakawan dan pemustaka). ${ }^{24}$ Penjelasan yang hampir sama diberikan oleh Abels (2003:2) yang mengungkapkan bahwa kompetensi profesional bagi praktisi informasi mencakup pengetahuan dalam bidang sumber-sumber informasi, akses, teknologi, manajemen, serta kemampuan untuk menggunakan pengetahuan tersebut sebagai dasar untuk menyediakan layanan informasi yang berkualitas. ${ }^{25}$

Pustakawan harus mengikuti perkembangan kemajuan ilmu pengetahuan dan teknologi informasi sehingga harus memiliki kreativitas dan inovatif, serta selalu membuka diri melihat informasi yang sedang berkembang. Dengan memiliki pustakawan yang kreatif dan inovatif dalam menjalankan tugasnya sebagai pustakawan akan memberikan nilai plus bagi perpustakaan dan pemustaka yang dilayani. Hal ini berarti pustakawan selalu

${ }^{23}$ Venus, Manajemen Kampanye: Panduan Teoritis Dan Praktis.

${ }^{24}$ Yeni, “Kompetensi Pustakawan Perpustakaan Khusus," 2011, https:// theyounglibrarian.wordpress.com/2011/04/16/kompetensi-pustakawanperpustakaan-khusus/.

25 Eileen Abels dkk., "Prepared for the Special Libraries Association Board of Directors by the Special Commitee on Competencies for Special Librarians," The Visual Computer Vol.24, No.3 (2003). 
berupaya untuk membangun kinerja ke arah lebih baik dan produktif dalam melaksanakan tugas-tugasnya. ${ }^{26}$

Berdasarkan penjelesan diatas keahlian seorang pustakawan tidak dapat berdiri sendiri melainkan dengan perpaduan dengan pengetahuan, pemahaman dan kemampuan dalam menyediakan layanan sehingga pemustaka memiliki kesan yang baik terhadap perpustakaan yang akan memicu meningkatnya loyalitas pemustaka.

\section{c. Hubungan Keterpercayaan Pustakawan dengan Loyalitas Pemustaka}

Keterpercayaan pustakawan memiliki hubungan signifikan dengan loyalitas pemustaka. Hasil uji korelasi dengan menggunakan metode korelasi pearson product moment didapat koefisien korelasi $\rho=0.444 ; \rho^{2}=0.197 ; \alpha=0.05 ; \mathrm{n}=102 ; \mathrm{dk}=100$, didapatkan hasil $\mathrm{t}_{\text {hitung }}=4.955$ dan $\mathrm{t}_{\text {tabel }}=1.984$, maka dinyatakan signifikan karena $t_{\text {hitung }}>t_{\text {tabel }}$

Selanjutnya dilakukan pentafsiran hasil menggunakan tabel intepretasi guilford

Tabel 1.3 Interpretasi Guilford

\begin{tabular}{ll}
\hline \multicolumn{1}{c}{ Interval Koefisien } & \multicolumn{1}{c}{ Tingkat Hubungan } \\
\hline $0,00-0,199$ & Korelasi Sangat Rendah \\
\hline $0,20-0,399$ & Korelasi Rendah \\
\hline $0,40-0,599$ & Korelasi Sedang \\
\hline $0,60-0,799$ & Korelasi Kuat \\
\hline $0,80-1,00$ & Korelasi Sangat Kuat \\
\hline
\end{tabular}

Maka dinyatakan bahwa hubungan antara keterpercayaan pustakawan dengan loyalitas pemustaka termasuk pada kategori korelasi sedang/moderat yaitu memiliki hubungan yang sedang artinya dengan keterpercayaan yang diberikan kepada pustakawan

${ }^{26}$ Abdul Bayu Asmara, "Upaya Pustakawan Perpustakaan Fakultas Kedokteran Universitas Indonesia Menjadi Pustakawan Cyber" (UIN Jakarta, 2015). 
ini dapat memicu loyalitas pemustaka pada perpustakaan, karena pemustaka menganggap bahwa pustakawan dapat dipercaya, jujur, dan bertanggung jawab dalam menyampaikan sebuah informasi yang dibutuhkan oleh pemustaka.

Hal ini selaras dengan pendapat James McCroskey, menjelaskan bahwa kredibilitas seorang pustakawan dapat bersumber dari kompetensi, sikap, tujuan, kepribadian dan dinamika. Dalam hal keterpercayaan meliputi sikap dan tujuan. Sikap menunjukkan pribadi komunikator apakah tegas atau toleran dalam prinsip. Tujuan menunjukkan apakah pembicara memiliki kepribadian yang hangat dan bersahabat. ${ }^{27}$

Courtesy is good service plus a little bit extra, and politness of manners combined with kindness. Courtesy adalah nilai yang harus dimiliki oleh seorang pustakawan seperti kesopanan, rasa hormat kepada sesama, dan menebar kebaikan. Pada prakteknya courtesy tingkatanya diatas nilai kesopanan dalam memperlakukan pemustakanya sehingga pemustaka merasa nyaman dan puas dengan pelayanan yang diberikan oleh pustakawan. ${ }^{28}$

Jadi implementasi Courtesy pustakawan adalah etika pelayanan yang baik yang diberikan oleh pustakawan kepada pemustaka seperti berbicara sopan, ramah tamah, dan saling menghormati. Untuk melakukan courtesy tersebut, maka pustakawan harus dapat menerapkan perilaku attentive, helpful, considerate, polite, dan respectfull. ${ }^{29}$

Dengan demikian penjelasan tersebut sesuai dengan hasil yang didapatkan pada penelitian ini bahwa keterpercayaan yang dimiliki oleh seorang pustakawan akan mendorong untuk pemutaka loyal terhadap perpustakaan karena informasi yang

27 Citra Mayasari, "Pengaruh Keramahan, Citra Karyawan, Dan Kepuasan Nasabah Terhadap Kedekatan Karyawan Dan Loyalitas Nasabah Produk Tabungan Bank Syariah Di Surabaya” (Perbanas, 2012).

28 Perpustakaan Nasional Republik Indonesia, "Pengembangan Kepribadian Pustakawan," Media Pustakawan Vol.17, No.3 (2010).

${ }^{29}$ Perpustakaan Nasional Republik Indonesia. 
didapatkan dari pustakawan dapat dipercaya terlihat dari sikap pustakawan yang tegas dalam menyampaikan sebuah informasi.

\section{d. Hubungan Daya Tarik Pustakawan dengan Loyalitas Pemustaka}

Daya tarik pustakawan memiliki hubungan signifikan dengan loyalitas pemustaka. Hasil uji korelasi dengan menggunakan metode korelasi pearson product moment didapat koefisien korelasi $\rho=0.527 ; \rho^{2}=0.288 ; \alpha=0.05 ; \mathrm{n}=102 ; \mathrm{dk}=100$, didapatkan hasil $\mathrm{t}_{\text {hitung }}=6.201 \mathrm{dan}^{\mathrm{t}_{\text {tabel }}}=1.984$, maka dinyatakan signifikan karena $t_{\text {hitung }}>t_{\text {tabel }}$

Selanjutnya dilakukan pentafsiran hasil menggunakan tabel intepretasi guilford

Tabel 1.4 Interpretasi Guilford

\begin{tabular}{ll}
\hline \multicolumn{1}{c}{ Interval Koefisien } & \multicolumn{1}{c}{ Tingkat Hubungan } \\
\hline $0,00-0,199$ & Korelasi Sangat Rendah \\
\hline $0,20-0,399$ & Korelasi Rendah \\
\hline $0,40-0,599$ & Korelasi Sedang \\
\hline $0,60-0,799$ & Korelasi Kuat \\
\hline $0,80-1,00$ & Korelasi Sangat Kuat \\
\hline
\end{tabular}

Maka dinyatakan bahwa hubungan antara daya tarik pustakawan dengan loyalitas pemustaka termasuk pada kategori korelasi sedang/moderat yaitu memiliki hubungan yang sedang artinya daya tarik sebagai salah satu faktor yang menentukan bahwa loyalitas pemustaka didapatkan karena adanya pustakawan yang memiliki daya tarik yang baik.

Secara umum konsep ini meliputi penampilan fisik dan identifikasi psikologis. Harap dipahami, pada konteks ini daya tarik berbeda dengan karisma. Seseorang mungkin saja mungkin saja menarik, tetapi tidak karismatik begitupun sebaliknya tetapi nilai-nilai yang ada pada orang tersebut sangat berbeda dan tidak menarik hati orang lain untuk melakukan identifikasi psikologis.

Daya tarik adalah sebagai faktor pelengkap dalam pembentukan kredibilitas yaitu apabila sumber komunikator 
tidak menarik atau tidak disukai maka untuk melakukan persuasi kepada pemustaka tidak akan berjalan secara maksimal. Terkadang persuasi yang dilakukan oleh komunikator yang tidak menarik perhatian atau tidak disukai oleh komunikan akan mengubah arah keberlawanan dengan yang dikehendaki oleh komunikator dalam hal ini pustakawan sebagai komunikator. ${ }^{30}$

Selaras dengan pendapat Cangara (2000:95) untuk mencapai komunikasi yang baik, seorang pustakawan harus mengenali dirinya sendiri dan harus memiliki faktor daya tarik selain kredibilitas yang dimilikinya.

Daya tarik pustakawan dinilai dimana pustakawan dianggap sebagai seorang memiliki karakter dan kesamaan nilai, hasil penilian pemustaka pada pustakawan di perpustakaan menyatakan bahwa pustakawan sudah memiliki daya tarik seperti menjaga kerapihan dan kebersihan di perpustakaan, dan terlihat sopan dalam berpakaian.

Dari penjelasan diatas daya tarik merupakan pelengkap dari komponen pembentuk kredibilitas yang harus dimiliki oleh pustakawan, hal ini ditunjukan dengan pustakawan memiliki daya tarik maupun kepribadian yang baik sebagai seseorang yang dipercaya untuk menyampaikan sumber informasi yang ada di perpustakaan sehingga pemustaka yang datang merasa puas terhadap pelayanan yang diberikan oleh pustakawan akan menghasilkan kesan yang positif terhadap perpustakaan dan secara tidak langsung pemustaka akan berkunjung kembali ke perpustakaan tersebut.

\section{Simpulan}

Berdasarkan pembahasan diatas didapatkan kesimpulan sebagai berikut (1) Kredibilitas pustakawan memiliki hubungan signifikan dengan loyalitas pemustaka. Dengan koefisien korelasi $\rho$

${ }^{30}$ Winoto, "The Application of Source Credibility Theory in Studies about Library Services," 3-5. 
$=0,537 ; \rho^{2}=0,288 ; \alpha=0,05 ; \mathrm{n}=102 ; \mathrm{dk}=100$, didapatkan hasil $\mathrm{t}_{\text {hitung }}$ $=6,366$ dan $t_{\text {tabel }}=1,984$, maka dinyatakan signifikan karena $t_{\text {hitung }}$ $>\mathrm{t}_{\text {tabel }}$. Hasil ini menunjukan bahwa pustakawan dapat memenuhi kebutuhan informasi pemustaka dan memberikan pelayanan yang baik pada pemustaka sehingga tercapai tingkat kepuasan dari pemustaka. (2) Keahlian pustakawan memiliki hubungan signifikan dengan loyalitas pemustaka. Dengan koefisien korelasi $\rho=0,362 ; \rho^{2}$ $=0,131 ; \alpha=0,05 ; \mathrm{n}=102 ; \mathrm{dk}=100$, didapatkan hasil $\mathrm{t}_{\text {hitung }}=3,883$ dan $t_{\text {tabel }}=1,984$, maka dinyatakan signifikan karena $t_{\text {hitung }}>t_{\text {tabel }}$. Hal ini berarti pustakawan memiliki wawasan dan pengetahuan. (3) Keterpercayaan pustakawan memiliki hubungan signifikan dengan loyalitas pemustaka. Dengan koefisien korelasi $\rho=0,444$; $\rho^{2}=0,197 ; \alpha=0,05 ; \mathrm{n}=102 ; \mathrm{dk}=100$, didapatkan hasil $\mathrm{t}_{\text {hitung }}=$ 4,955 dan $t_{\text {tabel }}=1,984$, maka dinyatakan signifikan karena $t_{\text {hitung }}>$ $\mathrm{t}_{\text {tabel }}$. Hal ini menunjukan bahwa pustakawan dalam menyampaikan sebuah informasi dianggap jujur dan memiliki integritas dalam memberikan jawaban, serta daya tarik pustakawan yang mengacu kepada kesaamaan, antara pustakawan dengan pemustaka. (4) Daya tarik pustakawan memiliki hubungan signifikan dengan loyalitas pemustaka. Dengan koefisien korelasi $\rho=0,527 ; \rho^{2}$ $=0,288 ; \alpha=0,05 ; \mathrm{n}=102 ; \mathrm{dk}=100$, didapatkan hasil $\mathrm{t}_{\text {hitung }}=$ 6,201 dan $t_{\text {tabel }}=1,984$, maka dinyatakan signifikan karena $t_{\text {hitung }}>$ $t_{\text {tabel }}$. Hal ini berarti pustakawan seperti bagaimana pustakawan itu berbicara, tingkat kesopan santunan, menjadi pribadi yang ramah terhadap pemustaka, bagaimana cara berpakaian layaknya seorang pustakawan yang dianggap kredibel dalam menyampaikan informasi kepada pemustaka nya.

Penilaian baik yang diberikan oleh pemustaka ini, akan memudahkan pustakawan dalam meningkatkan pelayanan secara prima terhadap pemustaka, hal ini secara tidak langsung akan mendorong seorang pemustaka memiliki loyalitas pada perpustakaan, karena melihat pustakawannya sudah memiliki kredibilitas yang baik maka pemustaka pun tak akan ragu untuk datang kembali ke perpustakaan. 


\section{DAFTAR PUSTAKA}

Abels, Eileen, Rebescca Jones, Jhon Latham, Dee Magnoni, dan Joanne Gard Marshall. "Prepared for the Special Libraries Association Board of Directors by the Special Commitee on Competencies for Special Librarians." The Visual Computer Vol.24, No.3 (2003).

Asmara, Abdul Bayu. "Upaya Pustakawan Perpustakaan Fakultas Kedokteran Universitas Indonesia Menjadi Pustakawan Cyber." UIN Jakarta, 2015.

Benawi, Imran. "Mengenal Lebih Dekat Perpustakaan Perguruan Tinggi." Jurnal Iqra Vol.06, No. 01 (2012). https://doi. org/10.1093/oxfordhb/9780199607617.013.31.

Karim, Abdul. "Urgensi Kompetensi Komunikasi Pustakawan Dalam Memberikan Layanan Kepada Pemustaka." Iqra Vol.05, No.1 (2011).

Mayasari, Citra. "Pengaruh Keramahan, Citra Karyawan, Dan Kepuasan Nasabah Terhadap Kedekatan Karyawan Dan Loyalitas Nasabah Produk Tabungan Bank Syariah Di Surabaya." Perbanas, 2012.

Perpustakaan Nasional Republik Indonesia. "Pengembangan Kepribadian Pustakawan." Media Pustakawan Vol.17, No.3 (2010).

- _- "Statistik Pustakawan Desember 2017 Pusat Pengembangan Pustakawan PNRI," 2018. http://pustakawan.perpusnas. go.id/pub/pustakawanstatistics? mode=monthly\&option=st at\&stat_month $=12 \&$ stat_year $=2017$.

Prijana, Yunus Winoto, dan Andri Yanto. Metode Penelitian Kuantitatif Ilmu Perpustakaan Dan Informasi. Bandung: Unpad Press, 2016.

Rakhmat, Jalaludin. Psikologi Komunikasi. Bandung: Rosda Karya, 2005. 
Rismayeti. "Perpustakaan Perguruan Tinggi: Pedoman, Pengelolaan Dan Standarisasi." Jurnal Ilmu Budaya Vol. 9, No. 2 (2013). https://www.ejurnal.unilak.ac.id/index.php/ jib/article/view/211/158.

Saleh, Amin. "Pengaruh Kredibilitas Pustakawan Pada Layanan Referensi Terhadap Kepuasan Pemustaka Di Badan Perpustakaan Dan Arsip Daerah Provinsi Nusa Tenggara Barat." Ilmu Perpustakaan Vol.1, No.1 (2014).

Santi, Triana. "Keterampilan Teknis Pustakawan." Jurnal Iqra Vol.06, No.01 (Mei 2012).

Saputro, Ropinov. "Analisis Pengaruh Kualitas Produk, Kualitas Pelayanan, Dan Kepercayaan Pelanggan Terhadap Loyalitas Pelanggan.” Universitas Diponegoro, 2010.

Tan, Alexis S. Pengantar Teori dan Manajemen Komunikasi. jakarta: Jurnal Press, 1981.

Tjiptono, Fandy. Manajemen Jasa. Yogyakarta: Andi Offset, 2000.

Venus, Antar. Manajemen Kampanye: Panduan Teoritis Dan Praktis. Bandung: Simbiosa, 2004.

Winoto, Yunus. "The Application of Source Credibility Theory in Studies about Library Services." EduLib Vol.05, No.2 (2015).

Woro, Mardikawati, dan Farida Naili. "Pengaruh Nilai Pelanggan Dan Kualitas Layanan Terhadap Loyalitas Pelanggan, Melalui Kepuasan Pelanggan Pada Pelanggan Bus Efisiensi." Jurnal Administrasi Bisnis Vol.02, No. 01 (2013).

Yeni. "Kompetensi Pustakawan Perpustakaan Khusus," 2011. https://theyounglibrarian.wordpress.com/2011/04/16/ kompetensi-pustakawan-perpustakaan-khusus/. 